\title{
CARACTERÍSTICAS ANATÔMICAS RELACIONADAS AO VALOR NUTRITIVO DE GRAMÍNEAS FORRAGEIRAS
}

\author{
ANATOMICAL TRAITS RELATED WITH NUTRITIVE VALUE \\ OF FORAGE GRASSES
}

Domingos Sávio Campos Paciullo ${ }^{1}$

- REVISÃO BIBLIOGRÁFICA -

RESUMO

Entre as características anatômicas relacionadas ao valor nutritivo de gramíneas, destacam-se a proporção de tecidos e a espessura da parede celular. Tais características apresentam altas correlações com os teores de fibra, de lignina e de proteína bruta $(P B)$ e com os coeficientes de digestibilidade in vitro da matéria seca (DIVMS). Os tecidos de baixa digestão correlacionam-se negativamente com a PB e a DIVMS e positivamente com os teores de fibra e de lignina, enquanto aqueles rapidamente digeridos mostram correlações positivas com a PB e com a DIVMS e negativas com os teores de fibra $e$ lignina. A digestão de alguns tecidos é limitada, não somente pelo efeito negativo da lignina sobre a digestão da parede celular, mas também pelo compacto arranjo das células de alguns tecidos e pela elevada espessura da parede celular. As relações entre a anatomia da planta e o valor nutritivo realçam a possibilidade da utilização de características anatômicas na avaliação do valor nutritivo de gramíneas forrageiras.

Palavras-chave: características anatômicas, digestão de tecidos, espessura da parede celular, proporção de tecidos.

\section{SUMMARY}

The tissue proportion and cell wall thickness are important anatomical traits influencing nutritive value of grasses. Theses characteristics present high correlation with fiber, lignin and crude protein $(C P)$ contents and in vitro dry matter digestibility (IVDMD) coefficients. The tissues lowest digested correlate negatively with $C P$ and IVDMD and positively with fiber and lignin contents, while the tissues rapidly digested show positive correlation with CP and IVDMD and negative with fiber and lignin contents. The digestion of some tissues is limited not only by negative effect of lignin on the cell wall digestion, but too by compact organization of cells of some tissues and by high cell wall thickness. The relationships between plant anatomy and nutritive value highlight the possibility of utilization of anatomical traits in evaluation of forage grass nutritive value.

Key words: anatomical traits, tissue digestion, cell wall thickness, tissue proportion.

\section{INTRODUÇÃO}

Pesquisadores das áreas de nutrição animal e de forragicultura têm procurado características inerentes às plantas forrageiras que possam expressar o verdadeiro valor de um alimento para os ruminantes. Algumas definições estabelecidas no final da década de 60 ainda são amplamente utilizadas na avaliação do valor nutritivo, pois nenhum avanço significativo foi observado desde aquela época (REID, 1994).

Estudos avaliando a influência da anatomia de gramíneas forrageiras sobre seu valor nutritivo têm sido desenvolvidos nas últimas três décadas (AKIN, et al., 1973; AKIN \& BURDICK, 1975; WILSON, 1976; WILSON et al, 1989a, b; 1991; QUEIROZ et al., 2000). Avanços nesta área

\footnotetext{
${ }^{1}$ Engenheiro Agrônomo, Bolsista de Recém-Doutor da Embrapa Gado de Leite. Campo Experimental de Coronel Pacheco. Rodovia Minas Gerais, 133, km 42, 36155-000, Coronel Pacheco, MG. E-mail: dscp@ terra.com.br.
}

Recebido para publicação em 24.04.01. Aprovado em 04.07.01 
foram possíveis graças à novas técnicas utilizadas em microscopia ótica e eletrônica (ENGELS, 1996). Esses estudos estabeleceram diferenças no potencial de digestão dos diferentes tecidos, possibilitando a associação entre a proporção de tecidos nos órgãos de espécies forrageiras e o valor nutritivo. De fato, foram demonstradas correlações significativas entre a proporção de tecidos, determinada em seções transversais de lâminas foliares e colmos de gramíneas e algumas entidades nutritivas (proteína bruta, fibra em detergente neutro, digestibilidade in vitro da matéria seca). Recentemente, trabalhos têm evidenciado que a baixa digestão de alguns tecidos pode estar mais relacionada a aspectos físicos dos tecidos, destacando-se a elevada espessura da parede celular, do que a características químicas, como os teores de lignina. Tais evidências demonstram a importância de se agregar os conhecimentos relacionados à anatomia da planta às avaliações do valor nutritivo de forrageiras.

\section{ANATOMIA DE GRAMÍNEAS}

As gramíneas são constituídas por um conjunto de órgãos (inflorescência, folha, colmo e raiz), cada um formado por tecidos. Estes, por sua vez, são constituídos por um conjunto de células com características químicas e estruturais próprias, desempenhando mesma função. Cada tecido possui composição química e física diretamente relacionada à sua função na planta. Assim, tecidos designados à sustentação da planta possuem células densamente agrupadas, com paredes espessadas e lignificadas. Por outro lado, tecidos relacionados ao processo de assimilação do carbono são ricos em cloroplastos e apresentam células com parede delgada e nãolignificada.

Os tecidos da lâmina foliar são diferenciados em tecidos condutores (feixes vasculares), consistindo das células do xilema e do floema; tecido de suporte ou sustentação (esclerênquima), que, em folhas de gramíneas, está freqüentemente associado aos feixes vasculares e ao tecido assimilatório, formado pelas células do parênquima clorofiliano que constituem o mesofilo. Ambas as superfícies da folha são cobertas pela epiderme, que, por sua vez, pode ser coberta na face exterior pela cutícula. Gramíneas $\mathrm{C}_{3}$ têm os feixes vasculares das folhas circundados por uma bainha de parede espessada na face interna e uma bainha de células com paredes delgadas mais externamente (WILSON, 1993). Os feixes vasculares são separados por um mesofilo com células esparçamente arranjadas. Nas gramíneas $\mathrm{C}_{4}$, observa-se, ao redor dos feixes vasculares, uma bainha de células grandes com paredes que apresentam espessura até cinco vezes à das células do mesofilo (WILSON, 1993). Esta bainha, denominada bainha parenquimática dos feixes vasculares, rica em cloroplastos, participa do processo fotossintético. Nas espécies $\mathrm{C}_{4}$, as células do mesofilo apresentam-se densamente arranjadas, formando uma estrutura radial ao redor dos feixes vasculares, denominado arranjo tipo Kranz.

O colmo das gramíneas apresenta um tecido parenquimático (no qual os feixes vasculares estão dispersos), um anel esclerenquimático que circunda todo o colmo e a epiderme mais externamente. Os feixes vasculares são semelhantes àqueles encontrados nas folhas, podendo ser circundados por um anel de fibras (esclerênquima). Nos estádios iniciais de desenvolvimento, apenas o xilema é lignificado. Mas, com a maturação, há progressiva lignificação, que inclui $o$ anel esclerenquimático e, em um estádio mais avançado, até o parênquima, onde os feixes vasculares estão inseridos (AKIN, 1989).

\section{PROPORÇÃO E DIGESTÃO DE TECIDOS}

A proporção de tecidos tem sido a característica anatômica usada como indicativo do valor qualitativo das forrageiras. A possibilidade de se associar esta característica com a qualidade nutricional de espécies forrageiras surgiu com a observação de que diferentes tipos de tecidos apresentam taxa e extensão de digestão diferenciadas (AKIN \& BURDICK, 1975). Assim, medidas da proporção dos tecidos com elevado conteúdo celular e/ou delgada parede primária (nãolignificada), de alta digestibilidade, e daqueles tecidos com baixo conteúdo celular e espessa parede celular (freqüentemente lignificada), normalmente associados à baixa digestibilidade, podem explicar diferenças qualitativas entre espécies e/ou cultivares de forrageiras (WILSON, 1997).

Em geral, as espécies $\mathrm{C}_{4}$ apresentam, na lâmina foliar, maior proporção de tecidos condutores, bainha parenquimática dos feixes e esclerênquima. Por outro lado, as espécies $C_{3}$ se destacam pela maior proporção de mesofilo, ocupando ao redor de $60 \%$ da seção transversal da lâmina foliar destas gramíneas.

A anatomia do colmo se mostra menos variável que a da lâmina foliar, tanto entre gramíneas do tipo $\mathrm{C}_{4}$ e $\mathrm{C}_{3}$, quanto entre espécies dentro de um mesmo grupo fotossintético (AKIN, 1989).

O potencial de digestão dos diferentes tecidos tem sido avaliado em seções transversais da 
lâmina foliar e do colmo. Têm sido utilizadas duas principais metodologias para observação em microscópio de luz: 1) incubações de fragmentos de 1 a $2 \mathrm{~cm}$ em líquido ruminal, com posterior desidratação, seccionamento em micrótomo, coloração e montagem em lâminas permanentes (HANNA et al., 1973; AKIN \& BURDICK, 1975; LEMPP et al., 1998; BRITO et al., 1999), e 2) incubações de fragmentos de 16 ou $100 \mu \mathrm{m}$ previamente aderidos à lâmina de microscópio por meio de fita adesiva de face dupla. Nesse caso, as lâminas, após incubação, são lavadas com água destilada e levadas diretamente ao microscópio para avaliação do desaparecimento dos tecidos (AKIN, 1982; WILSON et al., 1991; PACIULLO, 2000).

As vantagens e desvantagens de cada metodologia foram discutidas por ENGELS (1996).

Os estudos mostraram que os microorganismos colonizaram praticamente todas as partículas que chegaram ao rúmen. A maior rota de invasão parece ser via lesão da epiderme (CHESSON \& FORSBERG, 1988), embora a invasão pelo estômato possa ser importante para a colonização dos tecidos foliares (BRITO et $\boldsymbol{a l}$., 1999). As bactérias do rúmen digerem inicialmente as células do mesofilo e as do floema (HANNA $\boldsymbol{e t}$ al., 1973; AKIN et al., 1973), as quais possuem apenas uma delgada parede primária não-lignificada. Esses tipos de células são facilmente fragmentadas em partículas pequenas, sendo rápida e completamente digeridas (CHESSON et al., 1986).

Tecidos como o esclerênquima e o xilema, formados por células de parede secundária espessada, são os que mais contribuem para a baixa qualidade da forragem (AKIN, 1989; WILSON, 1993). Esses tecidos formam um sólido bloco multicelular no interior do rúmen, resultando em partículas de grande tamanho e pouco digeridas, em razão da lignificação e de problemas na acessibilidade dos microrganismos do rúmen à superfície da parede celular (WILSON \& MERTENS, 1995). Assim, os resíduos da digestão de gramíneas, independente do estádio vegetativo, contêm alta proporção de células esclerenquimáticas e xilema (AKIN, 1989). Em virtude de as células desses tecidos estarem densamente agrupadas, sua menor contribuição em área de tecido, freqüentemente, não reflete o efeito negativo que exercem sobre a qualidade do alimento. Em folhas de Lolium temulentum, essas células ocuparam $4 \%$ da área celular apenas, mas contribuíram com 19 e $43 \%$ em peso seco total e de parede celular, respectivamente. No colmo de sorgo, representaram
Tabela 1 - Digestão de tecidos de gramíneas forrageiras tropicais e temperadas.

Taxa e extensão da digestão de tecidos ${ }^{1}$

$\begin{array}{llll}\begin{array}{l}\text { Fração/origem } \\ \text { Folha/ tropicais } \\ \mathrm{C}_{4}\end{array} & \begin{array}{l}\text { Rápida e total } \\ \text { MES e FLO }\end{array} & \begin{array}{l}\text { Lenta e parcial } \\ \text { EPI e BPF }\end{array} & \begin{array}{l}\text { Não digerido } \\ \text { XIL e ESC }\end{array} \\ \begin{array}{l}\text { Folha/ } \\ \text { temperadas } \mathrm{C}_{3}\end{array} & \begin{array}{l}\text { MES, FLO, EPI } \\ \text { e BPF (depende } \\ \text { da espécie) }\end{array} & \begin{array}{l}\text { ESC e BPF (depende } \\ \text { da espécie) }\end{array} & \text { XIL e BIF } \\ \begin{array}{l}\text { Folmo/tropicais } \\ \text { e temperadas }\end{array} & \begin{array}{l}\text { FLO PAR } \\ \text { (imaturo) }\end{array} & \text { PAR (meia idade) } & \begin{array}{l}\text { EPI e ESC } \\ \text { (anel) }\end{array}\end{array}$

- MES- mesofilo; FLO- floema; EPI- epiderme; BPF- bainha parenquimática os feixes; ESC- esclerênquima; XIL- xilema; BIF- bainha interna dos feixes; AR-parênquima.

onte: Adaptada de AKIN, 1989.

$16 \%$ da área total, $38 \%$ do peso seco e $64 \%$ da parede celular (WILSON, 1993).

AKIN (1989), compilando resultados de diferentes trabalhos sobre digestão de tecidos (Tabela 1), sugeriu a divisão dos tecidos foliares de gramíneas $\mathrm{C}_{4}$ em rapidamente digestíveis (mesofilo e floema), lenta e parcialmente digestíveis (epiderme e células da bainha do feixe vascular) e indigestíveis (xilema e esclerênquima). Nas espécies $\mathrm{C}_{3}$, apenas o xilema e a bainha interna dos feixes são resistentes à digestão. Em uma posição intermediária, parcial e lentamente digestível, encontra-se o esclerênquima. São rapidamente digeridos o mesofilo, o floema e a epiderme. A bainha parenquimática dos feixes, nas espécies $\mathrm{C}_{3}$, pode ser lenta ou rapidamente digestível, dependendo da espécie.

No colmo, AKIN (1989) classificou a epiderme e o esclerênquima como indigestíveis, podendo-se incluir os feixes vasculares, exceto o floema. O parênquima imaturo e o floema são rápida e totalmente digestíveis, enquanto o aumento da idade reduz progressivamente a digestibilidade do parênquima (Tabela 1).

A combinação das informações de proporção com as de digestão de tecidos revela que a maior parte dos tecidos presentes na lâmina foliar das gramíneas de clima temperado $\mathrm{C}_{3}$ são rapidamente digeridos, enquanto nas espécies $\mathrm{C}_{4}$ estes tecidos representam uma menor proporção do total de tecidos. Por outro lado, nas gramíneas $\mathrm{C}_{4}$, os tecidos de digestão lenta e parcial, assim como os resistentes à digestão, ocupam a maior área da lâmina. Essas diferenças na proporção de tecidos explicam, em parte, a maior qualidade das lâminas foliares das espécies $C_{3}$ em relação às $C_{4}$.

Correlações altamente significativas entre a proporção de tecidos individuais, ou em combinação, e as características nutricionais têm 
sido observadas (WILSON et al., 1989a; QUEIROZ et al., 2000, PACIULLO, 2000). Tecidos com células rápida e totalmente digeridas, como as do mesofilo, apresentam correlações positivas com os coeficientes de digestibilidade e negativas com os teores de parede celular. Por outro lado, tecidos resistentes à digestão, como o xilema e o esclerênquima, ou de digestão lenta e parcial, como a bainha parenquimática dos feixes, e ainda a espessura da parede celular, correlacionam-se positivamente com os teores de parede celular e de lignina e negativamente com a digestibilidade.

Sobre a importância da anatomia no controle do consumo, MINSON \& WILSON (1994) ressaltaram que pouca atenção tem sido dada ao uso de fatores anatômicos, como a proporção de feixes vasculares em seções transversais da folha, para predição do consumo. Esses autores reconheceram algumas dificuldades neste tipo de estimativa, destacando o longo tempo requerido nas medições da área dos tecidos; a diversidade de fatores que influem no tamanho de partícula e na facilidade de fragmentação; e, finalmente, $\mathrm{o}$ fato de os experimentos sobre o consumo requererem grande quantidade de forragem, que, por sua vez, apresenta diferentes proporções de lâmina, bainha e colmo, cada uma com anatomia própria.

\section{ORGANIZAÇÃO DOS TECIDOS NA LÂMINA FOLIAR}

A epiderme de certas espécies $\mathrm{C}_{4}$ apresenta-se firmemente segura ao restante da folha por um suporte de células de parede espessa, formado pelo esclerênquima e pelas células da bainha do feixe vascular (WILSON et al., 1989b). Esta estrutura, conhecida como "girder", dificulta o desprendimento da epiderme do restante da folha, resultando em maior resistência da planta aos danos mecânicos e químicos. A resistência à digestão é maior em espécies que apresentam o suporte de células nas epidermes abaxial e adaxial ("girder" I), relativamente àquelas que apresentam o suporte apenas em uma das faces da epiderme ("girder" T) (WILSON et al., 1989b).

Também nas gramíneas de clima tropical, a ruptura das folhas durante a mastigação apresenta maior dificuldade, pelo fato de suas células epidérmicas possuírem paredes com contorno sinuoso, que resulta em mais forte junção de células, relativamente àquelas com paredes com superfície lisa, como na maioria das gramíneas de clima temperado (WILSON, 1994).

Ainda que facilmente degradado, o mesofilo nas gramíneas $\mathrm{C}_{4}$ é, pelo forte adensamento celular, mais lentamente digerido que nas espécies $\mathrm{C}_{3}$, cujas células são mais frouxamente arranjadas, apresentando poucos pontos de aderência entre si. BYOTT (1976) estimou que, em lâminas de gramíneas $\mathrm{C}_{4}$, existem de 3 a $12 \%$ de espaços intercelulares, enquanto nas $\mathrm{C}_{3}$ esses espaços representam de 10 a $35 \%$ da área do mesofilo. A maior quantidade de espaços intercelulares permite aos microrganismos ruminais rápido acesso às paredes das células, proporcionando elevada taxa de digestão à lâmina foliar. Além disso, facilita a fragmentação pela mastigação e a separação dos demais tecidos.

\section{BAIXA DIGESTÃO DE TECIDOS: LIGNIFICACÃ̃ $X$ ESPESSAMENTO DA PAREDE CELULAR}

A parede celular vegetal pode ser dividida em paredes primária, secundária e terciária. As duas primeiras camadas são as mais importantes e mais estudadas, embora WILSON (1993) tenha caracterizado a parede terciária como uma camada membranosa extremamente delgada, localizada internamente (lado do lúmen) à parede secundária.

A parede primária desenvolve-se simultaneamente à expansão celular. Em alguns tipos de células, como as do parênquima, esta é a única parede a se desenvolver. As paredes primárias de duas células contíguas são separadas por uma fina camada conhecida por lamela média, composta, principalmente, de substâncias pécticas. De acordo com WILSON (1993), a parede primária possui espessura média variando de 0,1 a $0,2 \mu \mathrm{m}$.

A parede secundária desenvolve-se internamente à parede primária, após completar-se a expansão da célula. Essa parede compreende três camadas $\left(S_{1}, S_{2}\right.$ e $\left.S_{3}\right)$, distinguidas pela orientação das microfibrilas de celulose. Não há evidências de diferenciação da digestão dessas camadas. A parede secundária com espessura variando de 1 a $5 \mu \mathrm{m}$ confere à célula resistência às forças de tensão e compressão. Geralmente, os tipos celulares que apresentam parede secundária se lignificam em maior ou menor grau (WILSON, 1993).

Quimicamente, a parede celular é uma matriz complexa composta de polissacarídeos, proteínas, compostos fenólicos, água e minerais. Dos polissacarídeos, destacam-se a celulose, a hemicelulose e a pectina. Existem fortes evidências de que os polissacarídeos isolados apresentam relativa facilidade de degradação pelos microorganismos do rúmen ou por enzimas isoladas (HATFIELD, 1989). Entretanto, a degradação 
desses polissacarídeos, quando presentes na parede celular, raramente é completada. A extensão da degradação varia conforme o tecido examinado, a espécie e a idade da planta. As interações dos componentes da parede, particularmente entre os polifenóis e os carboidratos, exercem as maiores restrições à degradação da parede celular (JUNG, 1989).

Dos componentes químicos associados à parede celular, a lignina é aquele que, reconhecidamente, limita a digestão dos polissacarídeos da parede celular no rúmen (JUNG \& DEETZ, 1993). Em geral, a lignina possui três álcoois aromáticos: álcool coniferil (que predomina nas espécies arbóreas), álcool sinapil e álcool pcoumaril (predominantes em gramíneas e leguminosas). Os termos "core" e "non-core" têm sido usados por alguns autores para diferenciar tipos de lignina em forrageiras (GORDON, 1975; JUNG \& DEETZ, 1993). O primeiro tipo (lignina "core") refere-se ao polímero de fenilpropanóides depositado na parede celular, pela polimerização dos álcoois precursores coniferil, sinapil e p-coumaril. Este tipo, determinado rotineiramente nas análises laboratoriais com uso de ácido sulfúrico $72 \%$, é extremamente condensado e também conhecido por lignina Klason ou lignina em detergente ácido (VAN SOEST, 1994). A lignina "non-core" representa os ácidos fenólicos $p$-cumárico e ferúlico (e seus dímeros) depositados na parede celular durante sua formação. Esses ácidos podem estar ligados à lignina "core", aos polissacarídeos ou a ambos, simultaneamente (JUNG, 1989).

Os ácidos fenólicos (lignina "non-core") presentes na parede celular das forrageiras mereceram maior atenção por parte dos pesquisadores a partir dos estudos de HARTLEY (1972), que mostrou correlações negativas entre as concentrações destes ácidos e a digestibilidade. Em geral, o ácido p-cumárico é o que apresenta maior efeito negativo sobre a digestibilidade de forrageiras.

Segundo JUNG \& DEETZ (1993), a lignificação da parede celular pode limitar a digestão dos polissacarídeos por meio de três possíveis mecanismos: 1) efeito tóxico de componentes da lignina aos microorganismos do rúmen; 2) impedimento físico causado pela ligação ligninapolissacarídeo, que limita o acesso das enzimas fibrolíticas ao centro de reação de um carboidrato específico; e 3) limitação da ação de enzimas hidrofílicas causada pela hidrofobicidade criada pelos polímeros de lignina.

Com relação à toxicidade causada por componentes da lignina, a maioria dos trabalhos indica o ácido p-cumárico como o mais tóxico aos microrganismos do rúmen, relativamente aos outros ácidos, embora este efeito só tenha sido observado em concentrações acima de $1 \mathrm{mM}$, normalmente não detectadas no fluido ruminal. Assim, a toxicidade causada pelos monômeros fenólicos liberados durante a digestão da parede parece improvável, devido à rápida difusão destas moléculas para fora da célula, por meio do fluido ruminal. Entretanto, se o gradiente de difusão do fluido não está presente, como em células do esclerênquima pouco fragmentadas, as concentrações de ácidos fenólicos no interior da célula podem, facilmente, alcançar os níveis tóxicos aos microorganismos (WILSON \& MERTENS, 1995). Além disso, o complexo ácido fenólico-carboidrato parece ser um produto comum resultante da digestão da parede celular (CHERNEY et al., 1992). Como o peso molecular deste complexo é elevado, sua taxa de difusão pode ser até 14 vezes mais lenta que a dos monômeros fenólicos isolados (WILSON \& MERTENS, 1995), o que pode causar toxicidade aos microorganismos ruminais. A extensão desta inibição parece pouco significante (JUNG \& DEETZ, 1993), uma vez que as bactérias possuem mecanismos de desintoxicação dos ácidos p-cumárico e ferúlico, pela hidrogenação da dupla ligação e produção do ácido 3fenilpropiônico (Chesson et al., 1982, citados por MARVIN et al., 1996).

De acordo com JUNG \& DEETZ (1993), não existe evidência direta que suporte a hipótese de limitação da digestão pela hidrofobicidade causada pela lignificação da parede celular. Segundo esses mesmos autores, o limitado acesso físico das enzimas hidrolíticas ao centro de reação do carboidrato parece ser a maior limitação à degradação da parede celular das forrageiras, em decorrência da lignificação.

Após a diferenciação e a maturação dos tecidos, a concentração de lignina na lamela média e na parede primária é mais elevada que na parede secundária, refletindo em maior efeito negativo na digestão dos tecidos. Além disso, na parede primária, a lignina encontra-se mais ramificada e mais estreitamente associada aos polissacarídeos que na parede secundária, a qual apresenta a lignina em uma forma mais linear (JUNG \& DEETZ, 1993). Essas características fazem com que a presença da lignina comprometa mais a digestão da camada da lamela média/parede primária que a digestão da parede secundária.

De fato, AKIN (1982) observou que a parede secundária das células esclerenquimáticas de gramíneas forrageiras apresentou considerável digestão no fluido ruminal, enquanto a lamela média 
e a parede primária permaneceram intactas. WILSON et al. (1991) verificaram diminuição de 54 a $85 \%$ na espessura da parede secundária das células esclerenquimáticas de três gramíneas de clima tropical, após 48 horas de incubação em fluido ruminal. Outros resultados confirmaram a digestibilidade variável da parede secundária lignificada de células do esclerênquima e dos vasos de metaxilema, além da completa indigestibilidade da lamela média e da parede primária lignificadas (GRABBER \& JUNG, 1991; WILSON et al., 1993). Assim, apesar de aparentemente intactos, tecidos como o esclerênquima e o xilema podem sofrer digestão parcial, com variável redução da espessura da parede secundária (PACIULLO, 2000).

Em gramíneas, quando os microorganismos têm rápido acesso à superfície da parede celular, a digestão da parede secundária parece não ser prevenida somente pela lignificação. WILSON \& MERTENS (1995) sugeriram que a espessura da parede celular e o arranjo das células nos tecidos podem limitar a digestão da parede secundária, tanto quanto ou até mais que a composição química da parede secundária.

CHESSON et al. (1986) demonstraram completa digestão das paredes das células do mesofilo (não-lignificada) isoladas de folhas de Lolium após 8 horas de incubação em fluido ruminal. Nesse caso, como a espessura média da

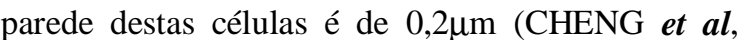
1980), obtém-se uma taxa de digestão em torno de $0,025 \mu \mathrm{m} /$ hora. WILSON \& HATIFIELD (1997) estimaram taxa semelhante para digestão da parede secundária lignificada do esclerênquima, enquanto PACIULLO (2000) encontrou taxas variando de 0,007 a $0,018 \mu \mathrm{m} / \mathrm{hora}$ para as gramíneas forrageiras Brachiaria decumbens, Melinis minutiflora e Cynodon sp.

A espessura das paredes das células do esclerênquima é fortemente influenciada pelo estádio de desenvolvimento e varia com a espécie.

$\mathrm{Na}$ literatura são encontrados valores de $1,30 \mu \mathrm{m}$ para Cenchrus ciliares (MOGHADDAM \&

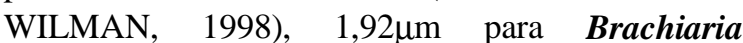

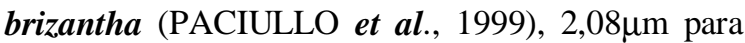
Melinis minutiflora, $2,72 \mu \mathrm{m}$ para Cynodon sp e 3,74 $\mu \mathrm{m}$ para Brachiaria decumbens (PACIULLO, 2000). Considerando a espessura média de $2,5 \mu \mathrm{m}$ e a taxa de digestão de $0,025 \mu \mathrm{m} / \mathrm{h}$, e assumindo que os microorganismos têm imediato acesso à superfície da parede, deduz-se que menos de $50 \%$ $(1,2 \mu \mathrm{m})$ da parede celular do esclerênquima será digerida após 48h. Dessa forma, mesmo que a parede celular esteja acessível ao microorganismo, a digestão não se completará durante o tempo de residência das partículas no rúmen. Pode-se deduzir que, quanto maior a espessura da parede secundária, maior será o tempo necessário para sua completa digestão.

Em células com parede espessa, existe a possibilidade de as bactérias não terem rápido acesso à parede celular para iniciar o processo de digestão. Nesse caso, a digestão poderá ser limitada não somente pela elevada espessura da parede secundária, mas também pela baixa acessibilidade dos microorganismos à parede celular. Para reforçar essa hipótese e estimar a relativa inacessibilidade, WILSON \& MERTENS (1995) demonstraram a influência da relação área superficial/volume de parede (AS/VP) das células do mesofilo, do esclerênquima e do parênquima do colmo. As espessuras das paredes celulares consideradas para cálculo foram de 0,$15 ; 1,0$ e $2,4 \mu \mathrm{m}$, respectivamente, para o mesofilo, o parênquima e o esclerênquima. Assumiu-se, ainda, que as células do mesofilo são digeridas nas superfícies externa e interna, enquanto para os outros dois tipos celulares a digestão ocorre apenas na face da parede voltada para o lúmen.

As estimativas da relativa exposição da parede celular (relação AS/VP) ao ataque microbiano e, conseqüentemente, à digestão, mostraram valores de 66:10:1 para o mesofilo, o parênquima do colmo e o esclerênquima, respectivamente. Isso significa que as células do esclerênquima isoladas são 66 vezes menos acessíveis aos microorganismos do rúmen que as células do mesofilo e 10 vezes menos que as células do parênquima. Portanto, mesmo na ausência de restrições químicas, é esperado que a digestão da parede do esclerênquima e de outras células com parede espessa seja parcial, em razão da pequena área superficial para a colonização bacteriana, relativamente ao elevado volume de parede a ser digerida. $\mathrm{O}$ problema pode ser agravado, tendo em vista que tecidos como o esclerênquima e o xilema, formam, após a mastigação, grandes partículas contendo centenas de células. Nesse caso, pelos cálculos de WILSON \& MERTENS (1995), a acessibilidade dos microorganismos ao bloco de células deve ser 180 vezes menor que em células do mesofilo.

A importância da relativa inacessibilidade à parede secundária, resultante da estrutura física da parede celular e do arranjo das células, é reforçada pelos resultados de GRABBER et al. (1992) e WILSON et al. (1993). Nesses estudos, diferentes tipos de tecidos isolados de folhas e colmos de gramíneas foram finamente moídos e incubados para 
digestão. Evidentemente, a maioria das características anatômicas limitantes à digestão originalmente encontradas nos tecidos foi destruída. Os resultados mostraram elevada digestão de células esclerenquimáticas fortemente lignificadas, evidenciando que as restrições físicas exercem importante papel no processo de digestão da parede celular.

A forte correlação negativa normalmente observada entre os teores de lignina $e$ digestibilidade de gramíneas forrageiras (JUNG $\boldsymbol{e t}$ al., 1997), em diferentes estádios de desenvolvimento, não invalida a hipótese de que a lignina não é o único fator importante responsável pela baixa digestão da parede celular. Isso porque, paralelamente à intensificação da lignificação, ocorre aumento das limitações estruturais com o desenvolvimento dos tecidos. No colmo, acontece maior esclerificação das células de parênquima, associada à formação e ao espessamento da parede secundária, o que também pode ser observado nas células do esclerênquima da folha.

\section{CONCLUSÕES}

A baixa digestão de alguns tecidos advém, principalmente, do arranjo adensado de suas células e da elevada espessura das paredes celulares que, geralmente, apresentam-se lignificadas. Contudo, estudos avaliando a influência da estrutura anatômica sobre a qualidade de gramíneas forrageiras ainda são escassos, tendo em vista o potencial de desenvolvimento desta área. A necessidade de se estabelecer um banco de informações a respeito da anatomia das diferentes gramíneas forrageiras torna-se evidente para permitir avanços no conhecimento das relações entre os fatores anatômicos e a qualidade das gramíneas forrageiras.

Por essa razão, determinações da proporção de tecidos associadas a medições da espessura da parede das células de alguns tecidos, como o esclerênquima, podem melhorar as estimativas do valor nutritivo de gramíneas forrageiras, bem como orientar trabalhos de melhoramento genético.

\section{REFERÊNCIAS BIBLIOGRÁFICAS}

AKIN, D.E. Section to slide technique for study of forage anatomy and digestion. Crop Sci, v.22, p.444-446, 1982.

AKIN, D.E. Histological and physical factors affecting digestibility of forages. Agron J, v.81, n.1, p.17-25, 1989.

AKIN, D.E., BURDICK, D Percentage of tissue types in tropical and temperate grass leaf blades and degradation of tissues by rumen microorganisms. Crop Sci, v.15, n.5, p.661-668, 1975.
AKIN, D.E., AMOS, H.E., BARTON, F.E., et al. Rumen microbial degradation of grass tissue by scanning electron microscopy. Agron J, v.65, n.5, p.825-828, 1973.

BRITO, C.J.F.A., RODELLA, R.A., DESCHAMPS, F.C., $\boldsymbol{e} \boldsymbol{t} \boldsymbol{a l}$. Anatomia quantitativa e degradação in vitro de tecidos em cultivares de capim-elefante (Pennisetum purpureum Schumach). Rev Bras Zootec, v.28, n.2, p.223-229, 1999.

BYOTT, G.S. Leaf air space system in $\mathrm{C}_{3}$ and $\mathrm{C}_{4}$ species. New Phytol. v.76, p.295-299, 1976.

CHENG, K.J., FAY, J.P., HOWARTH, R.E., $\boldsymbol{e}$ t al. Sequence of events in the digestion of fresh legume leaves by rumen bacteria. Appl Environ Microbiol, v.40, p.613-625, 1980.

CHERNEY, D.J.R., CHERNEY, J.H., PATTERSON, J.A. In vitro ruminal fiber digestion as influenced by phenoliccarbohydrate complexes released from sorghum cell walls. Anim Feed Sci Technol, v.39, p.79-93, 1992.

CHESSON, A., FORSBERG, C.W. Polysaccharide degradation by rumen microorganisms. In: HOBSON, P.N. (Ed.) The rumen microbial ecosystem. London : Elsevier Applied Science, 1988. p.251-284.

CHESSON, A., STEWART, C.S., DALGARNO, K., et al. Degradation of isolated grass mesophyll, epidermis and fibre cell wall in the rumen and by cellulolitic rumen bacteria in axemic culture. J Appl Bacteriol, v.60, n.4, p.327-336, 1986.

ENGELS, F.M. Developments in application of light and scanning electron microscopy techniques for cell wall degradation studies. Neth J Agric Sci, v.44, p.357-373, 1996.

GORDON, A.J. A comparison of some chemical and phisical properties of alkali lignins from grass and lucerne hays before and after digestion by sheep. J Sci Food Agric, v.26, p.15511559, 1975.

GRABBER, J.H., JUNG, G.A. In vitro disappearance of carbohydrates, phenolic acids, and lignin from parenchyma and sclerenchyma cell walls isolated from cocksfoot. J Sci Food Agric, v.57, p.315-323, 1991.

GRABBER, J.H., JUNG, G.A., ABRAMS, S.M., et al. Digestion kinetics of parenchyma and sclerenchyma cell walls isolated from orchardgrass and switchgrass. Crop Sci, v.32, p.806$810,1992$.

HANNA, W.W., MONSON, W.G., BURTON, G.W. Histological examination of fresh forages leaves after in vitro digestion. Crop Sci, v.13, n.1, p.98-102, 1973.

HARTLEY, R.D.P. Coumaric and ferulic acid components of cell wall of ryegrass and their relationship with lignin and digestibility. J Sci Food Agric, v.23, p.1347-1354, 1972.

HATFIELD, R.D. Structural polysaccharides in forages and their degradability. Agron J, v.81, p.30-46, 1989.

JUNG, H.G. Forage lignins and their effects on fiber digestibility. Agron J, v.81, p.33-38, 1989.

JUNG, H.G., DEETZ, D.A. Cell wall lignification and degradability. In: JUNG, H.G., BUXTON, D.R., HATIFIELD, R.D., et al. (Ed) Forage cell wall structure and digestibility. Madison: American Society of Agronomy, Crop Sci. Society of America, Soil Sci. Society of America, 1993. p.315-346. 
JUNG, H.G., MERTENS, D.R., PAYNE, A.J. Correlation of acid detergent lignin and klason lignin with digestibility of forage dry matter and neutral detergent fiber. J Dairy Sci, v.80, p.1622-1628, 1997.

LEMPP, B., EZEQUIEL, J.M.B., SANTOS, J.M., et al. Observação da taxa de digestão das células de mesofilo de duas cultivares de Panicum maximum Jacq., águas e seca. In: REUNIÃO ANUAL DA SOCIEDADE BRASILEIRA DE ZOOTECNIA, 35, 1998, Botucatu. Anais... Botucatu : SBZ, 1998. p.269-271.

MARVIN, H.J.P., KRECHTING, C.F., VAN LOO, E.N., $\boldsymbol{e}$ t al. Relationship between phenolic acids formed during rumen degradation of maize samples and in vitro digestibility. J Sci Food Agric, v.71, p.111-118, 1996.

MINSON, D.J., WILSON, J.R. Prediction of intake as an element of forage quality. In: FAHEY, G.C., et al. (Eds). Forage quality, evaluation, and utilization. Madison: American Society of Agronomy, Crop Sci. Society of America, Soil Sci. Society of America, 1994. p.533-563.

MOGHADDAM, P.R., WILMAN, D. Cell wall thickness and cell dimensions in plant parts of eight forage species. J Agric Sci, v.131, p.59-67, 1998.

MOTT, G.O., MOORE, J.E. Forage evaluation techniques in perspective. In: BARNES, D.C., CLANTON, C.H., GORDON, T.J. et al. (ed). Proc Natl Conf Forage Quality Evaluation and Utilization. Lincoln, Nebraska : Center Cont. Educ., 1969. p.1-7.

PACIULLO, D.S.C., MATTOS, J.L.S., GOMIDE, J.A., $\boldsymbol{e} \boldsymbol{t} \boldsymbol{a l}$ Proporção de tecidos e espessura da parede celular em espécies de braquiária, cultivadas sob diferentes níveis de umidade no solo. In: REUNIÃO ANUAL DA SOCIEDADE BRASILEIRA DE ZOOTECNIA, 36, 1999, Porto Alegre. Anais... Porto Alegre : SBZ, 1999. p.37.

PACIULLO, D.S.C. Características anatômicas e nutricionais de lâminas foliares e colmos de gramíneas forrageiras, em função do nível de inserção no perfilho, da idade e da estação de crescimento. Viçosa-MG, 2000. 104p. Tese (Doutorado em Zootecnia) - Universidade Federal de Viçosa, 2000.

QUEIROZ, D.S., GOMIDE, J.A., MARIA, J. Avaliação da folha e do colmo de topo e base de perfilhos de três gramíneas forrageiras. 2. Anatomia. Rev Bras Zootec, v.29, n.1, p.61-68, 2000 .

RAYMOND, W.F. Components in the nutritive value of forages. In: HARRISON, C.M., STELLY, M. BRETH, S.A. (ed). Forage economics - quality. S.1., 1968. (ASA Special Publication, 13).
REID, R.L. Milestone in forage research. In: FAHEY, G.C. (Ed). Forage quality, evaluation, and utilization Madison: American Society of Agronomy, Crop Sci. Society of America, Soil Sci. Society of America, 1994. p.1-58.

VAN SOEST, P.J. Nutritional ecology of the ruminant. 2.ed. Ithaca : Cornell University, 1994. 476p.

WILSON, J.R. Variation of leaf characteristics with level of insertion on a grass tiller. II. Anatomy. Aust J Agric Res, v.27, n.3, p.355-364, 1976.

WILSON, J.R. Organization of forage plant tissues. In: JUNG, H.G., BUXTON, D.R., HATIFIELD, R.D. et al. (Eds). Forage cell wall structure and digestibility. Madison American Society of Agronomy, Crop Sci. Society of America, Soil Sci. Society of America, 1993. p.1-32.

WILSON, J.R. Cell wall characterisitcs in relation to forage digestion by ruminants. J Agric Sci, v.122, n.2, p.173-182, 1994

WILSON, J.R. Strutural and anatomical traits of forages influencing their nutritive value for ruminants. In: SIMPÓSIO INTERNACIONAL SOBRE PRODUÇÃO ANIMAL EM PASTEJO, 1997, Viçosa. Anais... Viçosa : UFV, 1997. p.173-208.

WILSON, J.R., MERTENS, D.R. Cell wall accessibility and cell structure limitations to microbial digestion of forage. Crop Sci, v.35, n.1, p.251-259, 1995.

WILSON, J.R., HATIFIELD, R.D. Structural and chemical changes of cell wall types during stem development: consequences for fibre degradation by rumen microflora. Aust J Agric Res, v.48, p.165-180, 1997.

WILSON, J.R., ANDERSON, K.L., HACKER, J.B. Dry matter digestibility in vitro of leaf and stem of buffel grass (Cenchrus ciliares) and related species and its relation to plant morphology and anatomy. Aust J Agric Res, v.40, n.2, p.281-291, 1989a.

WILSON, J.R., AKIN, D.E., McLEOD, M.N., et al. Particle size reduction of the leaves of a tropical and temperate grass by catlle. II. Relation of anatomical structure to the process of leaf breakdow through chewing and digestion. Grass and Forage Sci, v.44, n.1, p.65-75, 1989b

WILSON, J.R., DEINUM, B., ENGELS, F.M. Temperature effects on anatomy and digestibility of leaf and stem of tropical and temperate forage species. Neth J Agric Sci, v.39, n.1, p.31-48, 1991.

WILSON, J.R., MERTENS, D.R., HATFIELD, R.D. Isolates of cell types from sorghum stems: digestion, cell wall and anatomical characteristics. J Sci Food Agric, v.63, p.407417, 1993. 